\title{
Whose Security? Deepening Social Conflict over 'Customary' Land in the Shadow of Land Tenure Reform in Malawi
}

\author{
Pauline E. Peters and Daimon Kambewa
}

CID Working Paper No. 142

March 2007

(C) Copyright 2007 Pauline E. Peters, Daimon Kambewa, and the President and Fellows of Harvard College

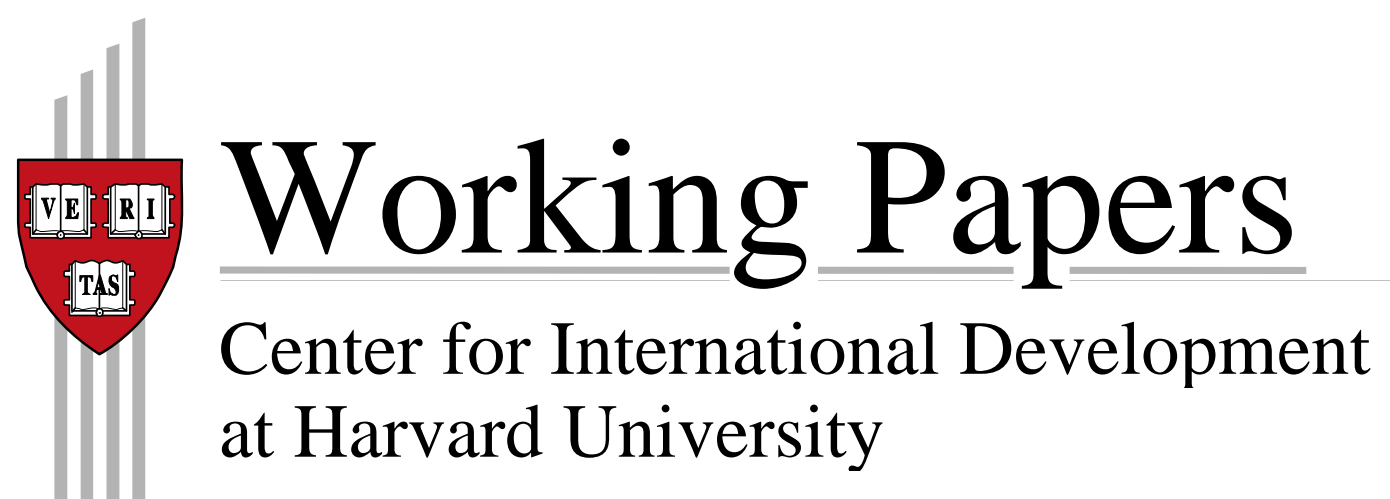




\title{
Whose security? Deepening social conflict over 'customary' land in the shadow of land tenure reform in Malawi ${ }^{\#}$
}

\author{
Pauline E. Peters ${ }^{*}$ and Daimon Kambewa ${ }^{+}$
}

\begin{abstract}
Malawi, like other countries in Africa, has a new land policy designed to clarify and formalise customary tenure. The country is poor with a high population density, highly dependent on agriculture, and the research sites are matrilineal-matrilocal, and near urban centres. But the case raises issues relevant to land tenure reform elsewhere: the role of 'traditional authorities' or chiefs vis-à-vis the state and 'community'; variability in types of 'customary' tenure; and deepening inequality within rural populations. Even before it is implemented, the pending land policy in Malawi is intensifying competition over land. We discuss this and the increase in rentals and sales; the effects of public debates about the new land policy; a new discourse about 'original settlers' and 'strangers'; and political manoeuvring by chiefs.
\end{abstract}

Keywords: land tenure, land reform, land rentals and sales, Malawi

JEL codes: Z1

\footnotetext{
\# Accepted for publication in Journal of Modern Africa Studies

* JFK School of Government, and Anthropology Department, Harvard University

${ }^{+}$Bunda College, University of Malawi. A preliminary version of the paper was written by Peters and presented to a conference held by IRD, Montpellier, France in May 2006. Acknowledgements are due to our research respondents and assistants, Professor Paul Kishindo, and the JMAS reviewers.
} 
Malawi is one of the poorest countries in the world, and its economy is dependent on agriculture (as well as on foreign aid), exporting tobacco (which alone contributes over half of the value of exports), tea and sugar, along with a range of food crops. Most people live in rural areas (84\%, down from $91 \%$ in 1977), and draw on land for their own consumption as well as for produce for sale. Since the end of the colonial period, land has increased steadily in value as population has risen, as new crops and crop varieties have been introduced, and, especially over the past two decades, as gaining a reasonable livelihood for most in the face of national and regional political-economic setbacks has become more difficult. The commercial value of land, both for its products and for non-agricultural uses (residences, tourism, market centres, etc.), is highest within reach of markets, the main towns and roads, the lake shore, and access to international borders.

The country has experienced considerable policy and political change over the past decades. Under the autocratic Dr Banda (from independence to 1994), the 'dual' structure of agriculture was reinforced, whereby estates retained the privileged right to produce the most valuable crops, while smallholders were required to sell their crops at lower prices to the marketing board. The result was a hidden subsidy to the estates, because the surplus built up by the board was funnelled through banks as soft loans to Malawian estate owners (Kydd \& Christiansen 1982). The supposed 'market miracle' of Malawi, as it was celebrated through the 1970 s, was a smoke-and-mirrors way to privilege a small elite. Banda's regime came to an end in 1994, when the country entered the period of 'multiparty politics'. This political change interacted with economic processes and the overly 
strong influence of donor aid on policy reform (Harrigan 2003). Flawed programmes of structural adjustment and market liberalisation put in place from 1981 were too hastily implemented, and mistakenly assumed that a private market would emerge immediately. Instead, the results were a food crisis by 1987 (Harrigan 1988, 1997; Sahn et al. 1990), and a failure of the private market to ensure adequate and affordable supplies of the staple maize in the food-deficit period - a failure exacerbated by erratic government performance that continues to the present.

A recent assessment of the 'challenge for rural development' in Malawi repeats the overall story of a rural population with a "narrow range of risky and low productivity activities ... exacerbated by poor infrastructure, services and communications ... low ... education and literacy $\ldots$ and poor health exacerbated by the spread of HIV/AIDS' (Dorward \& Kydd 2004: 346), and concludes that 'private sector investment has not replaced the parastatal system that aspired to support rural investment' (ibid.: 352-3). The authors call for a more proactive and more accountable state that seeks to provide livelihood and investment supports to agriculture. Similar hopes for political and policy approaches designed to improve small-scale farming for both economic growth and equity are widespread for Africa (Lahiff \& Cousins 2005; May et al. 2004) and more broadly (Griffin et al. 2002). Unlike the Dorward and Kydd paper, all the latter include land tenure reform as a central but not a sole platform for such a renaissance. Problems in the way of achieving this goal include mounting competition and conflict over land, not only in the case discussed here but more broadly (see below), as well as the political will and capacity of governments and their donors to provide the requisite levels of public investment (Dorward \& Kydd 2004; Sender \& Johnston 2004; Walker 2005). ${ }^{1}$ 


\section{LAND TENURE AND THE NEW LAND POLICY}

Malawi, formerly Nyasaland, is a country carved out along the huge Lake Malawi, largely through colonial rivalries between the British and Portuguese. Previously, the region was settled over thousands of years by people coming from the west and north, some of whom over time formed kingdoms. Early European travellers described people in the central and southern region as Maravi, whence comes its current name. The history of land tenure starts later, imported as an alien idea and set of practices by the Europeans. David Livingstone, the most famous missionary-explorer of his time, publicised Nyasaland in his writings and lectures as a country rich in land, generally pleasant in climate, with friendly and industrious inhabitants, but increasingly vulnerable to Muslim slavers, so portraying it as ripe for the benefits of 'Christianity and Commerce'.

The highlands of the river Shire soon attracted missionaries and traders, and the proximity to Southern Rhodesia brought it within the ambit of Rhodes' British South Africa Company. The region had long been part of trade networks (for gold, ivory, slaves, salt), with Swahili entrepôts on the shores of Lake Nyasa (Malawi). As slaving and gun-running increased in the mid-nineteenth century, Yao groups were moving into the southern region, some peaceably, others contesting the suzerainty of the Nyanja chiefdoms. The area also attracted the attention of the Portuguese in neighbouring Portuguese East Africa (later Mozambique). Between Livingstone's fourth trip in 1859 and the arrival of the first party of missionaries (the Universities' Mission to Central Africa) in 1861, the Shire Highlands had 
dissolved into fighting between rival groups - mainly the long-established Nyanja, incoming Yao, and raiding parties of Ngoni spun off from the Zulu state to the south, and slave traders. The failure of the UMCA mission at Magomero (see White 1987) did not deter others, missions and traders, settling from the 1870 s on. By 1890 , a number of estates had been carved out. Among them was the single largest block of 169,000 acres, obtained by Buchanan for Alexander Low Bruce, a millionaire investor in African exploration and development, and the son-in-law of David Livingstone. ${ }^{2}$ In 1891, the British government declared a Protectorate over the region, its reluctance finally overcome by growing anxiety over Portuguese intentions to take over the Highlands, lobbying by the Europeans settled in the territory, and, significantly, Cecil Rhodes' agreement to contribute money to the cost of administration. 'Conceived by the missionaries and delivered by Rhodes, British Central Africa was born' (White 1987: 81).

The estate owners found it difficult to obtain sufficient labourers and, after some experiments, devised the thangata system. This Chinyanja term referred to a collective work-group, which the estate owners interpreted self-interestedly as a kind of labour tribute given to chiefs and to which they, as new owners of the land, laid claim. The terms of the resulting labour tenancy were generally onerous and became a central site of social struggle (Kandawire 1977; White 1987), and even today thangata is used to refer to any kind of oppressive control or 'slavery'. Most of the tenants on the Shire Highlands estates eventually came to be Lomwe-speaking migrants from Portuguese East Africa, fleeing the even more oppressive conditions there (Pike \& Rimmington 1965: 134; Vail 1983: 50). By the end of World War I, the Protectorate Administration was aware of the build-up of resentments over labour conditions as well as over land scarcity. An enquiry into the 
famous Chilembwe rising of 1915, in the area of the Bruce estate and in which several white estate managers were killed, concluded that it was fuelled by exploitative labour practices and land shortage for Africans living on 'crown' land as well as families living on estate land. The unrest increased through the economic stringencies of the 1930s and war years of the 1940s. A Land Ordinance passed in 1951 defined land as public, private or customary, though the latter was a type of public land, which remained under the ultimate control of the Protectorate Governor.

After political independence was achieved in the early 1960s, Dr Banda turned away from his earlier promises to reverse the dualistic economy that privileged estates, towards a stance that did not differ much from the colonial views about customary tenure. In 1967 he stated in Parliament that, 'Under the present method of landholding and cultivation we can never hope to develop this country economically with agriculture as the backbone of our economic development' (quoted in Mbalanje 1986). His expressed opinion of customary land tenure was that, "No one is responsible ... Land is held in common ... and everybody's baby is nobody's baby at all' (Ng'ong'ola 1982: 115). This reflected a deeplylaid prejudice against 'communal' land as imagined by Europeans (Peters 1994, 2004), and echoes the opinions of colonial officers on land tenure (Ng'ong'ola 1982). ${ }^{3}$ The Malawi Registered Land Act was 'largely based on the Kenya Registered Land Act 1963', and passed in 1967 (Mbalanje 1986). The one effort, based on the new laws, to title land in Lilongwe, led to more disruption than the intended increase in production and land markets. As other studies of titling programmes across Africa have found, the intentions ran aground on the time taken to identify, demarcate and title land (with only a tiny area finally covered), the problems of identifying the unit of land ownership, and the tendency 
for chiefs and family elders to control the knowledge and practices, leading to younger men and many women losing rather than gaining security. Another conclusion common to titling programmes is that 'a simple conversion of titles cannot bring about agricultural development; land reform must be accompanied by the availability of credit and improved marketing infrastructures' (Ng'ong'ola 1982: 131).

The Banda regime shifted gears, using regulation and marketing boards to obtain agricultural products from the mass of smallholders, while providing the political elites the carrot of leased estates. These expanded during the 1970s and 1980s, withdrawing land from the customary sector, and causing disruption and unrest in several areas of the country, although this was generally not known outside Malawi because of Banda's tight control on the news media. For a confluence of reasons, including mismanagement, overextended capitalisation, and the effects of the oil price hike and its aftermath, many of these estates were failing by the early 1980s. The overall stress on the economy and a weakening in the regime led to the government being forced to accept structural adjustment and liberalisation policies, some of which had severely negative effects on the wider population, but which also opened production of the high value crop, burley tobacco, to smallholders, and, with a rise in public protest, to the demise of the Banda government and the entry of 'multiparty' democracy by 1994.

In 1996, a Presidential Commission of Inquiry on Land Policy Reform was established to 'recommend the main principles of a new land policy which will foster a more economically efficient, environmentally sustainable and social equitable land tenure system' (Holden et al. 2006: 13). Its 1998 report recognised the variation in customary tenure rules (including a major difference between matrilineal and patrilineal forms), 
repeated that the privatisation through the Lilongwe Land Development Programme had not achieved the ends of greater security of ownership, negotiability of title or a 'robust land market', and expressed a concern at the 'historical wrong' done to the people of the crowded Southern Region by the alienation of land to Europeans and for which 'it is not unreasonable that demands for some form of land readjustment are being asserted in those areas' (cited in Holden et al. 2006: 13-4). The final report was submitted in 1999, and a draft policy 'was circulated and discussed with groups including traditional leaders and civil society representatives' among others (ibid.).

The Malawi National Land Policy was approved by Cabinet and Parliament in 2002. A Special Law Commission was set up in 2003 to review all land-related laws, and to conduct a further series of consultative workshops with civil society. Even after that date, the draft policy has continued to be a subject of public debate, including the formation of Land Net with a representative on the Special Commission, and it had still not been passed into law as of early $2007 .{ }^{4}$ The stated purposes of the policy include: to clarify and strengthen 'customary land rights' and to formalise the role of 'traditional authorities' ${ }^{5}$ in the administration of customary land that now covers about $70 \%$ of national land (ibid.). ${ }^{6}$ The policy provides that customary landholders will be able to register their land as 'customary estates'. These will have 'private usufructuary rights in perpetuity, and once registered, the title of the owner will have full legal status and can be leased or used as security for a mortgage loan' (GoM 2002: 4.7.2c). The definition of a 'customary estate' is given as 'land with secure tenure by families, corporations, organisations and individuals' (ibid. 4.7.2a), hence, the unit for titling is not specified. As the term usufructuary implies, there is no provision for outright sales. The Special Commission has recommended having only two 
types of land, private and public; formerly customary land that becomes titled will be private, and any unallocated customary or chiefdom land (graveyards, grazing areas, etc.) will be a form of public land (Holden et al. 2006).

In both past law and the new policy, a central idea is that titling is a way of 'unifying the law', replacing the dualism of customary and statutory with a unitary law (Mbalanje 1986). This, in turn, was and is assumed to increase security for landholders and, thereby, lead to investment and increased productivity. Experience across Africa throws considerable doubt on this outcome from titling alone, and reveals broader social and political economic circumstances as more determinant (Bruce \& Mighot-Adholla 1994). On the other hand, the considerable variation in actual practices concerning land formally under customary tenure, and the evidence of competing claims over land (discussed below), suggest that titling may provide a further means by which some individuals and families secure their land (possibly at the expense of others), even though it is unlikely (except for very large holdings) to be suitable for collateral against a bank loan, or to directly improve use and investment.

There are two areas where the new policy does strike out in a different and more activist direction. Because of concern about reports of discrimination against women in access to land, the policy provides for all children, irrespective of sex, to inherit land (and other property) from parents. This, if actually implemented, is likely to dispossess women of their existing rights in matrilineal-matrilocal areas, like those described in this paper. The policy also specifically identifies past failure of accountability and transparency in allocations and judgments on land by Traditional Authorities (TAs), as well as acts of appropriation of land by the central government. The policy seeks both to recognise the 
longstanding authority of TAs, but also to ensure more accountability by 'formalising' the system of land administration. But the effects, as discussed below, are to intensify conflicts between existing rights and claims and those embodied in the policy, and to increase rather than decrease the scope of authority of the TAs and lower-level chiefs (cf. Kishindo 2004).

CONTEMPORARY LAND USES AND STRUGGLES OVER LAND

The research drawn on for this paper is from two studies conducted mainly in Zomba district in the Southern Highlands. ${ }^{7}$ This is one of the most densely populated areas of the country, and home to the twin-city of Blantyre-Limbe, one of the two largest manufacturing and commercial centres (the other is the capital, Lilongwe in the Central Region), as well as the medium-sized town of Zomba. Several rivers run through the area, disgorging into Lake Chilwa, a lake without an outlet that periodically dries in drought years, but is a very rich source of fish in years of decent rainfall. In general, agriculture dominates, and is practised by the large smallholder majority as well as by a number of small to medium sized estates. The latter grow flue-cured and burley tobacco as their principal crops, though most also grow maize, other food crops, tree crops, or spices. The principal crops for smallholders are maize, root crops, legumes, rice (in the wetlands), and a wide range of vegetables, as well as tobacco (mostly burley with a little dark-fired) as the most valuable key cash crop. ${ }^{8}$ As in most of the country (and indeed, much of Africa), rural families depend heavily but not solely on agriculture, drawing income from off-farm 
sources of temporary waged jobs, small-scale businesses, and migrant remittances from family members working elsewhere.

Although land occupied and used by smallholder families is legally under customary tenure (as contrasted with private freehold or leasehold land and public land), in crowded areas such as those where the research took place, the existing situation more resembles family tenure (Peters 1997, 2002). In Zomba and neighbouring districts, people practice matrilineal inheritance and succession ${ }^{9}$ and matrilocal residence (where the husband moves to his wife's village). One consequence of the latter, which distinguishes this area from some other matrilineal groups in Malawi, ${ }^{10}$ is that most women work land belonging to their own matrilineal group, and most men use land belonging to their wives.

This is statistically and normatively the pattern revealed in research data collected from households in the Zomba South longitudinal study since 1986, and was also found in the Chilwa Study 2001-2004. It is also revealed in how people respond if asked how land is transferred: they say 'our daughters inherit the land and our sons leave - they get land from their wives' family'. In the few cases in the research villages where a man is using land belonging to his own matrilineage, the reasons include that he is young, or is between marriages and thus considered to be needing 'help', until he marries and obtains land from his wife's family; and/or that his matrilineal group has ample land relative to the 'daughters' (female matrilineal heirs) claiming the land. In most of these cases, tension builds and finally the men are forced by their matrilineal 'sisters' to give up their matrilineal land and move to their wives' villages or elsewhere. Because a high proportion of marriages take place between people from the same district, often neighbouring villages, distances between spouses' natal homes/lands are often quite small. 
In light of these findings, the aim of the land policy to shift inheritance from the lineal patterns to bilateral, that is, for all children irrespective of gender to inherit, will have the effect of dispossessing women of their land rights in the matrilineal-matrilocal areas, such as that described here. The outcome in patrilineal-patrilocal areas would be different, and more likely to benefit some women (widows, unmarried sisters and daughters).

Virtually all people in the research area are well aware of the general shortage of arable land and the competition over it. Most of the disputes recorded within matrilineal groups as well as between them in the villages turn on land, discussed in detail elsewhere (Peters 1997, 2002), but the upshot is that there is net migration out of the area, with sections of matrilineal families leaving in every generation. The disputes over land appear to be associated with deepening splits within matrilineages; in short, there is a narrowing in the definition of lineage or sub-lineage. ${ }^{11}$ This narrowing in definition of belonging is part of a wider process of intensifying socio-economic differentiation. In the Zomba South longitudinal study, for example, the difference between the income (broadly understood to include cash income and agricultural value of food) of the top $20 \%$ and the bottom $20 \%$ of sample households increased from a ratio of 4 to 1 in 1986 to 11 to 1 in $1997 .^{12}$ This statistic, which is echoed in national data and other research, is reflected in status markers of housing type, clothing, furniture, bicycles, vehicles and other assets, as well as in educational and occupational levels. Clear differences mark off those with wealth and social influence; they include the bigger traders concentrated in the market centres, all of which have increased in size, those with larger landholdings and the wherewithal to produce many crops, some of the chiefs, as well as some of the higher officials of government departments based in the rural areas. 
The deepening social differentiation occurring across the country takes specific cultural shape through lifestyle and affiliation, including membership of the increasingly large number of Christian and Islamic sects/groups, and patterns of consumption, all of which serve to distinguish between people from the same region, village or clan. While our research has focused on rural life, the markers of differentiation are even more obvious in the towns, where a distinct elite is ever more visible through high levels of consumption in, for example, Sunday attire at churches, highly orchestrated weddings, and other key social ceremonies. ${ }^{13}$ The growing social differentiation in Malawi, the heterogeneity among rural people, and the complex social dynamics at play cannot be addressed here, but they need to be stressed as a background to our discussion of competition over land. ${ }^{14}$

Another indication of intensifying competition over land emerging from the research is the spread of practices of renting land, and of increases in the rents charged. There has long been quite a lot of borrowing of land by relatives and by friends. Such loans are almost always for a season at a time and without direct payment, although small gifts such as a small amount of a crop may be given after harvest. Increasingly, however, transfers of land for a season are taking the form of renting, mostly between non-relatives. Some use the term rent (rendered in a Chinyanja-ised English as renti or lenti), others use the Chinyanja term that means borrow and lend. The passing of money sometimes helps to clarify the usage. A more robust indication is that the amount of money being exchanged for transfers of land, whether these are referred to as borrowing or renting, has been steadily increasing since $1986 .{ }^{15}$ The highest payments are for the valuable irrigated land (the stream-bank or wetland gardens, known as dimba), which are used for growing vegetables and maize for sale in the dry season and, since the early 1990s when smallholders were allowed to grow 
burley tobacco, for the tobacco nurseries set up in September-October. Research in 2006 revealed more complaints about the difficulties of even finding dimba to rent. A recent report documents rentals of land for several districts of Malawi, and concludes that 'land rentals are on the increase' (Holden et al. 2006: 46), though it expresses dissatisfaction with the shortage of empirical studies of rural rental markets and with 'the astonishing ... absence of critical thinking and distinction between land sales markets vs. land rental markets in the Malawian land policy documents...' (ibid.: 52).

In the situation described here, where all arable land is under cultivation, the role of the chiefs is no longer or only rarely that of allocator as stipulated in the conventional description of customary tenure. In the few cases where fields have been re-allocated in the research villages, the user has left the village and there are no claimants to the fields. In short, usually fields are passed on through matrilineal inheritance, and the chief's role is as judge or arbiter in dispute cases. In other areas of Malawi where land is more plentiful (relatively speaking), chiefs have more land to allocate, and the propensity for chiefs to sell land of which they are supposed to be trustee is one of the stated concerns of the land policy (see below). Some of the net migration out of the research area is of people who move to areas just to the north and west seeking land.

Transfers between villagers themselves appear to be on the rise. In addition to the increase in renting and the level of rents observed in the Zomba South study over the past two decades, sales of land are becoming more common, even though they remain unusual. The first types of sales found in the study since the mid-1980s were of land immediately surrounding the trading (market) centres scattered throughout the rural areas. The buyers are the bigger traders in these centres, and the fields sold to them by individuals in the 
surrounding villages are used more often for buildings or brick-making, rather than for cultivation. These still constitute most sales of 'customary' land.

Since the mid-1990s, however, and more particularly in the past five years, there has been an increase in sales of fields for cultivation between farmers themselves. ${ }^{16}$ Unsurprisingly, the buyers are always the better-off families, those who are already in the largest land-holding categories, and who have the highest production and income levels. The sellers vary: some are poor families who, for historical or genealogical reasons, have more land than they need or manage to cultivate, and who need cash more than future security in land. Some are individuals in families who want cash, and who ignore or defy family disapproval to sell a field to non-family members. In a recent case, one individual, described as 'fierce' by relatives, determined to sell off a field and when the family did not manage to dissuade him ${ }^{17}$ from this intention, a female member of the matrilineage with her husband came forward with money to buy it. In this way, we were told, the field would remain within the control of the matrilineal 'daughters'. In most other cases occurring in the research villages, however, the sale has been to a non-family/lineage member. In all these cases, the ability of the person or family selling was described as being that they had more than enough land or that there were no heirs or claimants currently wishing to retain the land. The prices recorded vary considerably, partly due to the quality and size of the fields but also, it appears, to the relatively new situation and a wider range of negotiation. In the cases where fairly large areas of land were sold, the local village headperson was said to have been informed and to have witnessed the transfer. Nevertheless, problems arise. 
From a simple notion of supply and demand, these 'sales' resemble market transactions: as land becomes less available relative to the number of people needing it, those with the ability to raise cash in a desperately cash-short environment are able to make a bid for land. Yet, even as the process goes forward, some of the buyers express concern about whether the sales will 'stick'. One married couple who are among the most successful farmers in the sample had moved to a neighbouring village where they were able to purchase land from a family with more land than they needed (as well as being allocated a field and area for a house by the chief, in the more normal and normative way). Their reasons were that first, the man had been farming on land belonging to his matrilineage, and as his 'sisters' (including what Europeans would define as cousins) matured, he had been asked to leave the land for the proper heirs, the matrilineage's 'daughters'. And second, they had many growing daughters of their own for whom they wished to provide fields as they married; the wife's own matrilineal group from whom the daughters should have received land had insufficient for all. However, even though the couple had the village chief witness the sale in the presence of some of the seller's family, after three years in this favourable situation, during 2006 the couple said that they were still worried that after their deaths, the descendants of those who sold them the land might try to claim the land back.

Their worries are well-founded since, even as sales are taking place, more are being disputed by one section of a matrilineal family against another. One case concerns a family living in the wife's village, as is the norm, using a field belonging to her, but who wanted more land to cultivate. They are a well-off family and have regularly rented a field from various people over the years, but three years ago bought a large field for the extraordinary price of K60,000 (about \$430) from a person in a neighbouring village. In 2006, the chief 
of the village of the seller joined with a section of the family of the seller to bring a case against the buyer. Their claim was that the seller was not the proper 'owner' of the field, and so had no right to sell. The case went to the Traditional Authority (the regional chief) and then to the District Commissioner. Both said that unless the plaintiff family paid back the money, the buyer should retain the field. However, a few months later, the buyer told us that he had been physically threatened and was 'tired' of spending time and resources on the case (gossip had it that both sides had paid the chiefs and TA bribes), so had left the field to the seller's family.

A case in another village recently concluded. It was brought by two guardians (ankhoswe) or uncles (mother's brothers or ambuye) against a woman who had sold three fields to four different families in her village. The guardians did not live in her village, but in a village near Zomba town where they were married. They said she had not informed them of her intention and thus she had no right to sell the fields without the knowledge of the guardians, and they reclaimed the fields. The buyers all said they had bought the fields in good faith when the woman seller had approached them asking for 'help' in obtaining the cash she needed for various family costs. Some quoted dates and amounts of cash given (K2650 [\$19], K9000 [\$64]) though the latter was believed by all to be exaggerated), and one said the chief had witnessed the sale. The seller denied these statements and declared that she had rented out the fields not sold them. In the court's decision, the chief and his counselors said that while the guardians were correct to say that the sales could not be accepted without their knowledge and consent, he also chided them for neglect of their 'daughter', asking them where they were when she needed the help for which she went to her fellow, unrelated, villagers. The chief concluded that the guardians and the erstwhile 
buyers should go with him to the fields and divide them into a larger section for the guardians' matrilineage and a smaller section for the buyers. He asked the plaintiffs to sit aside to discuss this ruling. They returned and said that since the fields were not very big, they would prefer that the biggest one should be chosen and divided between the buyers, while their own matrilineage would retain the other fields. This was agreed. A few months later, they reneged on this acceptance, and accusations and hinted threats of bewitchment were traded between them and the chief. The case remained there in December 2006.

It is instructive to note that in these cases, no-one had objected to the sales on the basis of the land being under customary tenure and thus on the illegality of sales, which would be the reading from the existing law. The TA in the first case merely complained about not being involved in the original deal; and the issue in the second case turned on the knowledge and acceptance of the recognised guardians of the matrilineage. In sum, sales of land are becoming more common, but disputes over the meaning of 'sale' are also increasing. As in other parts of Africa, transfers that appear to be sales are sometimes redefined, even after a generation or two, as loans.

\section{Wetlands and irrigable lands}

So far, our discussion has focused on upland or dry-land areas, but the newest type of land that has come under intensifying use and over which research revealed increasing competition and conflict is the wetlands. In a region where there is only one rainfall season per year (and that subject to periodic failure), agriculture is very vulnerable to climatic variability. Thus, irrigable land along streams and in seasonally wet areas has long been valued, and historians have documented the use of dimba gardens cultivated in such lands, 
since at least the early $19^{\text {th }}$ century (Mandala 1990). These have become ever more valuable. ${ }^{18}$ Until about ten to twenty years ago, however, the large area of true wetlands surrounding Lake Chilwa was used only for seasonal grazing of livestock as well as catching birds and small animals. This has now changed. There has been a net increase in cultivation, including a conversion of wetlands to rice production, and in settlement, and a net loss in woods and wetlands (Jamu et al. 1999). The Chilwa study on small-scale irrigation over the past three years revealed intensification in use of stream-bank and wetland areas, and a related increase in competition and conflict over their control and use. Two dimensions of this situation are the rising value of watered areas, and increasing numbers of people seeking to gain access to them, an increase due not only to population growth typical of the country but also to in-migration.

The distribution of watered gardens is a product of several interacting processes: ecological and climatic, historical patterns of settlement, and current political and policy initiatives. Villages settled along rivers and streams, on flood plains, or in low-lying seasonally flooded areas, have a higher proportion of people with watered gardens than others. 'Original' settlers and relatives of the village head's lineage are more likely to have stream-bank and wetland gardens than others. These ecological and historical processes interact with more recent influences on the distribution of access to watered land. First, watered land has gained even more value in people's eyes in the wake of increased volatility in weather patterns over the past two decades. Second, the irrigation schemes established mainly in the 1970s significantly boosted rice production, revealing the attractions of the crop for food and cash. Third, there has been an increasing response to the demand for foodstuffs by the growing number of urban and peri-urban consumers, as well 
as by buyers in local markets; and greater diversification in family income strategies. Fourth, several significant changes in policy direction have intensified interest in and concern over the valuable watered lands, including the promotion by government, donors, and NGOs of small-scale irrigation, and the recent shift in government policy to hand over the smallholder irrigation schemes to farmers. These, along with public discussion about the new land policy as well as the continuing influence of multi-party politics, have served to generate and intensify competing claims over land and water.

Farmers using stream-bank gardens are unanimous in their opinion that these constitute the major source of cash income, as well as contributing towards the family food supply. In addition to cultivation, other uses of rivers include sand and gravel extraction, consumption by animals, drawing water for brick-making, household needs (bathing, washing clothes, food processing), and fishing. Most competition, however, comes from the mounting demand for these gardens. Similarly, the demand for cultivation plots in wetlands (dambo) has sharply increased over the past decade.

\section{Competition and conflict over watered land}

In the upland areas of the Zomba South study, which have been in use for generations and in permanent cultivation for over fifty years, most streambank gardens are, as described above, in the hands of matrilineal families and are transferred within the family. Only a third of the sample families own dimba, and increasing competition over the gardens has led to more of them being rented out and their rents increasing over the past 15-20 years. The Chilwa Study showed that the wetlands, concentrated on the floodplains of Lake Chilwa, where the rivers flow into the lake, have come under cultivation more recently, and 
their use is one source of severe conflict. A second source of conflict derives from the government plan to hand over the formal irrigation schemes to the plot-holders.

As more people have sought plots in the wetlands for cultivation, particularly for rice though also for maize and vegetables, several consequences arise. The first is conflict between claimants who are being distinguished as 'strangers' or 'latecomers' (obwera, literally, those who have come), and those claiming status as locals and first settlers/owners. People have long moved into the Chilwa Basin for fishing, small game hunting, and cattle grazing. Some of these incoming men have married into resident families (recall that this area is matrilocal), and some, already married and with a family they wish to settle, have managed in the past to obtain land for cultivation from chiefs. The formation of the irrigation schemes also attracted people looking to cultivate rice to come to the area. The increasing uses and rising value of the wetlands have produced competition and conflict. The tendency for these conflicts to be described as between local residents and strangers appears to be fairly new in Malawi, ${ }^{19}$ and as in other parts of Africa, carries the danger of overt conflict. In some of the cases of dispute over specific pieces of land, some of those said to be 'newcomers' are also described - in what is a great insult - as serfs (akapolo) since they are said to descend from people who were taken captive in small-scale wars, or given as pawns or sold into slavery by their own people. While most of the time the past histories of groups interfere little in daily life, the intensifying competition for land has drawn such histories into the forefront of dispute.

Another, and related, source of conflict emerges from the ways in which chiefs treat wetlands and their allocation for gardens. Unlike the Chilwa stream-bank gardens sample described above, where many of the garden owners were related to the village headmen, 
less than a third were so related in the wetlands sample. This difference derives from two facts: first, wetlands, earlier used for grazing, have been converted to cultivation more recently than stream-bank gardens, and second, village headmen and superior chiefs have allocated gardens to non-villagers. The second is related to the first in that the norms of customary tenure - concerning chiefs as trustees of land on behalf of their subjects - are much weaker over wetlands; before they came under cultivation, wetlands were more akin to commons. The sampled wetland plot users were found to consist of those who had inherited plots from their matrilineal elders $(60 \%)$, and those who had received plots directly from a chief ( $40 \%)$. The rent charged by the individual owners ranged between K200 to K1000 [\$1.5 - \$7] per plot in 2004-5.

The big difference lay with the wetlands controlled by chiefs. Quite unlike the situation with dryland fields (minda) or the stream-bank fields described above, some of the wetland plots were held on the basis of various conditions, especially that of giving the allocating chiefs annual tribute. The obligation to pay tribute, a word translating the Chinyanja word chothokoza, literally 'thanks', is a reinvention of an older tradition. In the past, those allocated plots by a village head or other chief would give a chicken and/or brew beer as a token of thanks. Today, in the densely populated Highlands area, this traditional token has long disappeared from the use of dry land fields and stream-bank gardens, almost all of which are inherited within families. Until fairly recently, the chiefs received such thanks in the form of a token K100 or so as chamalo (literally, of the land or place). Its use by the chiefs allocating wetland plots against an annual payment has a very different connotation from the past token of respect and thanks. The payment to the allocating chiefs was reported in 2004-5 to be a bag of rice per plot, since the plots are overwhelmingly used for 
growing that crop. More recent information (given to Kambewa in January 2007) from one chief who rents out a large number of these gardens is that the payment is now K2000 plus 2 bags of rice per plot, per season. ${ }^{20}$ The chiefs normally have a 'committee' of men, drawn from their advisers, relatives and friends, who collect the payments; they receive portions of the collected rice and, less often admitted, some is given to higher-level chiefs. In addition to these thanks paid in rice, some respondents said that urban dwellers with access to cash (usually as wage or salary earners) often paid up-front in cash to gain access to these plots. So far, we have far less information on these than on the local farmers' payments of rice.

In some ways, this practice resembles a rental market, and the allocating chiefs resemble landlords. The payments have increased over the past couple of decades as the value of plots has increased, reflecting the small supply of plots relative to the demand for them from both local residents and town dwellers. On the other hand, they are still referred to by many as payment of thanks rather than a rent; some (but not all) of the chiefs allow their fellow chiefs, their relatives and close allies/friends to have plots without payment, and may also waive the payment for a user who becomes sick or suffers some family crisis. For others, these payments resemble rents, albeit with the special modifications mentioned, than they provide token thanks to the chief. Moreover, some chiefs denounce their peers for exacting payments, even in the name of thanks, arguing that to act so in the name of chieftaincy is an illegal act that goes against the role of chief as guardian. Yet even that stance is not clear cut. Other chiefs told the researchers that, observing some of their peers gaining an income from exacting payments for wetland plots, especially in light of what 
they consider to be meagre allowances and salaries given them by government, they are considering starting such a practice.

\section{Competition over land in small-scale irrigation schemes}

In turn, this situation is profoundly affected by the current programmes for 'handing over' the formal irrigation schemes to farmers where ownership of land has become a focus of dispute, as well as by the discussions about the impending new land policy. As noted above, government managed the formal irrigation schemes in the Chilwa basin. Under the Banda regime, the schemes were described as being for settlement and rural development. Members of the Malawi Young Pioneers, a youth brigade of the then ruling Malawi Congress Party, were placed in the schemes, along with local residents who received plots as part of the compensation for the state takeover of customary land. These Pioneers acted as police to the scheme administration (managed by the Ministry of Agriculture), so that rules of planting times, crop choices, and water management were enforced. The coming of multi-party politics entailed the disbanding of the MYP (with some violence at first), and a broader breakdown in institutional and administrative systems. The irrigation schemes are an example. ${ }^{21}$ The schemes also suffered from a withdrawal of government resources and, through the 1990s, a decline in the overall national economy. The outcomes have been deterioration in the irrigation infrastructure (canals, etc) and the inability of remaining authorities to enforce rules. The schemes do vary. One of those researched was riven with conflict between farmers, because of the failure of some to follow rules of planting, opening and closing of water canals, etc. The other had done better and still ran as a single 
scheme, even though there was considerable inequality in the distribution of plots and authority within the scheme.

It is in this context that the government has decided, with the help of aid donors, to hand over the schemes to be managed by farmers. The rationales include one of privatisation as well as of decentralised control. This is a complex story (see Ferguson \& Mulwafu 2004, forthcoming) but here we concentrate on what the research found in respect of the land on which the schemes are set.

There are longstanding sources of conflict between farmers in the irrigation schemes and those in areas surrounding the schemes. Most concern the movement of water, but as the government plans to hand over the schemes to the scheme farmers became known, conflict emerged over land. As noted earlier, the schemes were originally established on land taken out of customary tenure by government. In the new policy of handover, the status of the land has become unclear and contested. Officials in the central ministries say that the land is to remain under the ownership of the government, and that the farmers' water user associations, which are to be set up as part of the handover, will receive a lease for the scheme land. The research found, however, that many local government officials, scheme managers, and many farmers did not know this or did not accept it. Many farmers said they thought the land was going to revert to customary land, and some understood this as meaning that the plots would become their own (equivalent to the family property typical of the area, though formally under customary tenure). A smaller number thought the land would remain government property, and even fewer said the new farmers' associations would be the owners. 
The responses from local chiefs also varied but they had more immediate effect. Some chiefs of the surrounding villages insist that the land does not belong to government but to themselves (the chiefs), because it was expropriated from them to set up the irrigation schemes, and they claim to have the right to allocate it as they see fit. One of the earliest indications of this was that, when the announcement was made that the schemes were to be handed over to the plot users, one or two of the chiefs whose villages surround the schemes evicted users who were not members of their villages, and reallocated the plots to their own villagers. The disputes resulting from these actions brought to the fore the differences in claims being made over the irrigation schemes.

One dimension echoes that of the conflicts emerging in the wetlands, namely, between locals and newcomers. 'One of the most contentious debates relates to who will have rights to access plots in the schemes after handover. Is it people from surrounding villages, any person from Zomba or Machinga Districts [the districts within which the schemes are established], or any citizen of Malawi?' (Ferguson \& Mulwafu 2004: 10). The chiefs who wish to reclaim the land in the irrigation schemes, on the basis of its having been expropriated for the original settlement of the schemes, do so partly in the name of traditional claims but also in the name of democracy. Much of the political rhetoric that led to the fall of the Banda regime and to the coming of multiparty politics is precisely in the name of democracy, citizens' rights, and similar notions. Yet exactly the same ideas are taken as justifications by some of the scheme farmers to reject the stance of the chiefs who are trying to reassert their rights over the scheme land. Some say that the chiefs do not own the land but are trustees, and that the plots should belong to those who have cultivated them for years. Some say that the government owns the land but is lending it to the farmers on 
the scheme, and chiefs should not be involved at all. Yet others, echoing the official government view, say that the land should belong to the new (and to be formed) associations of users of the scheme plots.

Attempts by local representatives of the Ministry of Agriculture, who still exercise authority over the schemes until the handover is completed, have failed so far to have the situation of relative rights over land clarified and resolved by the senior chiefs (Traditional Authorities) and by the District Commissioners. This is partly because the rights of the cases are far from clear, and so produce differing interpretations, and partly because of political alliances and divisions among all involved. In turn, this situation has been exacerbated by the discussions of the new land policy.

\section{The new land policy}

The policy is intended to increase the security of land rights for the majority of Malawians living on land formally under customary tenure. The policy associates increased insecurity in land with 'fraudulent disposal of customary land by headmen, chiefs and government officials' (GoM 2002: 2.4.2, 4.18.2). In order to make the process as 'transparent and democratic' as possible, the policy seeks to set up customary land committees 'headed by the Headperson [and] composed of Three (3) recognized and respected community elders (at least one being a woman) who will be elected in accordance with tradition to serve as members' (ibid.: 5.12.1a). In addition, each district will have a Traditional Land Clerk 'trained in land tenure issues ... to maintain a record of land transactions occurring within the TA [Traditional Authority area]' (ibid.: 5.12.1b). 
Despite the fact that there has been clear recognition of many problems with customary tenure, the policy remains at some remove from the actual practices about land revealed by the research. First, the role of the chiefs (from headmen to the higher-level chief or Traditional Authority) is more complex and contested than imagined. The situation is not merely one of illegal acts, but one where such acts are entangled in struggles over legitimate authority over land. Research reveals different categories of the population drawing on elements of the ideal image of customary tenure such as notions of trusteeship and entitlement based on family and locality, as well as on more commercial ideas. The issue is not simply that 'fraudulent disposal ... may deprive some holders of the right to land' but that, in a context where there is not enough (usable) land for everyone to have a viable amount, social conflicts arise over whose claims have priority over particular areas. ${ }^{22}$ Moreover, policy shifts - particularly the handover of irrigation schemes to farmers, decentralisation of government, and the new land policy itself - have intensified competition over valuable lands and have provided new or reinvigorated rationales for supporting claims, particularly those of locality and 'custom'. In this case, to make the chiefs chairpersons of the new land allocation committees seems misconceived. While the longstanding respect accorded to the role of chief (even if not always to the specific holders of the roles) suggests they should definitely be members of the new committees, it would be wiser not to give them even greater authority over decisions than they have today (cf. Kishindo 2004). In some earlier drafts, the policy document provided for the chief to be an ex officio member of the new land administration committee, but in its most recent form, it specifies that the chief be chairperson. The debate generated by the new land policy has led to an enormous amount of politicking around land and authority over land at all levels of 
society, including strong opposition by the most senior and vocal chiefs in the country against any perceived modification in their authority over land. For now, they seem to have won (cf. Holden et al. 2006: vii). ${ }^{23}$

A second issue concerns the valuable stream-bank gardens. The land policy documents do not distinguish these from the upland (dryland) that forms the majority of customary landholdings. Yet the increasing value of these lands means that claims over them are particularly fraught. This omission is a particular challenge for the policy's hope for more equitable distribution of land. A similar problem exists with reference to wetland gardens. The policy makes a few references to wetlands (dambo) that assume them to be 'common access' or 'public' land within the overall category of 'customary' tenure. It states:

Within a Traditional Authority, the community's public land will include all land within the boundaries of the TA not allocated exclusively to any group, individual or family. This designation applies in particularly to dambos, dry season communal grazing areas, etc. Such common access or unallocated customary land reserved for the community are regarded as public only to members of that community and will be protected. (GoM 2002: 4.2.4b, original stress).

In turn, this assumption leads to the policy providing an option for privatising wetlands by a group: "Any grouping of families and individuals living in a locality or having customary land rights in a defined area, that seeks to protect their common property interest or "dambo" shall be recognized and legally protected as common property' (ibid.: 5.6.1d).

The assumption here is that the wetlands remain unallocated and are treated as common or public land for members of the 'community', defined as residents in the area under a Traditional Authority. The premise is that the TA acts as trustee for such 'common' lands. 
In fact, the situation in the wetlands, at least as found in the Chilwa Basin and described above, is highly variable. Thus, rather than the policy's assumption that, in the case of competing interests in an area of wetlands (or other common lands), 'all existing rights and encumbrances' can be incorporated, the reality more often is that there are incompatibilities between existing uses and rights that will need far more detailed analysis and action than mere demarcation.

A further concern is with the unit of titling. The policy refers to individuals, families or other groups in a broad brush way. Given the problems encountered in the 1970s effort in Lilongwe over the titling unit and over whose names appeared on the title, this may be wise. On the other hand, the policy also allows for the name of the 'head' of a family to be registered as the proprietor of family land, and the to-be-formed Customary Land Committee will subsequently 'record partitions of customary estate lands and changes in family heads' (Holden et al. 2006: 19). Such a recording of the 'head' will result in men's (as husbands and brothers) names being recorded with a likely loss to women and young men. This interpretation of 'head' will be followed even in the matrilineal-matrilocal areas described here, but will not reflect the ways in which land is allocated, used and transferred in which women as daughters and wives have far more authority.

Finally, there are likely to be much greater problems over demarcating boundaries than expected. The policy intends to demarcate the boundaries of the TA 'in order to protect the villagers' land rights and promote better and sustainable use of the natural resources within villages' (GoM 2002: 7.6.1). A new phenomenon that we have not been able to discuss in this paper is the way in which villages are splitting. Groups (at the centre of which is a lineage claiming rights to a chiefship) are lobbying the Group Village Headmen and TAs, 
often successfully, to allow them to set up a new village under a new, named chief. A key rationale is that the many types of distributions (food, fertiliser and seeds, boreholes, etc) experienced over the past 10 years, partly due to the explosion of NGOs entering the country, have led people to assume that they have more chance of gaining from these programmes if they have their 'own' village. This dynamic is not taken into account in plans for the land reform. ${ }^{24}$

\section{Conclusion}

While this paper has concentrated on the situation in Malawi, where there are specific circumstances in the national and more localised situations discussed, there are also clear parallels with processes occurring and documented in other countries in Africa. A considerable amount of published and ongoing research has documented the pervasiveness of competition and conflict over land and landed resources across Africa. The social conflict over land has been described as entangled with competition and conflict over authority between elders (or seniors) and juniors, between traditional authorities or chiefs of various stripes and younger educated groups, between men and women, between locals and migrants, between autochthones and strangers, and between state and people (among others, see Amanor 2001; Besteman \& Cassanelli 1996; Juul \& Lund 2002; Klopp 2000; Nyambara 2001; Peters 2004; Richards 2005).

Research has also described various modes of 'informal formalisation': that is, ways of providing more formal recognition of transfers of land (often through writing) than the customary oral means (Benjaminsen \& Lund 2003). These transfers include not only the usual modes of transfer to heirs either after or before the death of a land-holder, but also the 
newer ones of rent and sale. The discussions of these raise the same issues as indicated above for Malawi: how to account for the appearance or increase in incidence of such transfers in systems still legally labelled as customary and usufructuary, and how to define such transfers, including whether or not they are market transactions. Research in francophone West Africa has pushed the discussion the furthest. The land transfer practices described by Chauveau 2006 for Cameroun, Mathieu et al. 2003 for Burkina Faso, and Colin \& Ayouz 2006 for Ivory Coast, some of which translate as the recipient giving a payment as 'thanks' to the donor, resemble those described above for Malawi. They have certain resemblances to a commodity transaction (such as the relation between quality or size of land and payment), but also (in Malawi) to obligations to a wider group such as a lineage or (in West Africa) to patronage, in which social obligations owed by the recipient (sometimes a migrant) to the donor do not disappear.

The shortcomings of state-led land reform have been well-rehearsed in the literature, some of which has been outlined above, on the failure of registration and titling programmes alone to improve productivity or provide collateral for credit, or even to increase security for land holders. Yet a simple shift from state to 'community' or 'the local' for land reform runs against the mounting evidence of increased inequality in access to land, intensifying competition and conflict over land with deepening rifts between and within kin, ethnic and regional groups, and expropriation of land by local and non-local agents. Intensification of production, increased reliance on markets for inputs and basic necessities, growing populations and mobility, state demarcation of forest and conservation areas, and political manoeuvring over the place of 'traditional authorities', state, and community, have all intensified competition over land. ${ }^{25}$ One outcome is the already 
advanced state of transfers - mainly rentals but also sales - a circumstance which the Malawi Land Policy seems not to take seriously. For example, making rentals 'legal' does not require titling and is likely to have an immediate, mainly positive effect. Many of those renting out cannot manage to cultivate the land itself due often to transitory circumstances (lack of inputs, illness), yet fear claims on the fields by renters if the renting is beyond one season. Overall, the complexity of claims and transfers suggests that a strict division between state-led and community-led reform produces an unsupportable dichotomy. Yet while a 'mixed' approach seems called for, it faces considerable challenges, including taking serious account of actual practices rather than idealised systems or law on the books, and asking whose security is gaining or losing rather that assuming that security inheres in a particular type of tenure (private, individual), or a legal procedure, such as titling. 


\section{REFERENCES}

Amanor, K.S. 2001. Land, Labour and the Family in Southern Ghana: a critique of land policy under neo-liberalisation. Uppsala: Nordiska Afrikainstitutet Research Report no.116.

Bassett, T.J. \& D.E. Crummey, eds. 1993. Land in African Agrarian Systems. Madison, WI: University of Wisconsin Press.

Beall, J., S. Mkhize \& S. Vawda. 2005. 'Emergent democracy and "resurgent" tradition: institutions, chieftaincy and transition in KwaZulu-Natal', Journal of Southern African Studies 31, 4: 764-71.

Benjaminsen, T.A. \& C. Lund, eds. 2003. Securing Land Rights in Africa. London: Frank Cass.

Berry, S.S. 2002. 'Debating the land question in Africa', Comparative Studies in Society and History 44, 4: 638-68.

Besteman, C. \& L.V. Cassanelli, eds. 1996. The Struggle for Land in Southern Somalia: the war behind the war. Boulder, CO: Westview.

Bruce, J. \& S.E. Mighot-Adholla. 1994. Searching for Land Tenure Security in Africa. Washington, DC: World Bank.

Bryceson, D.F. 2006. 'Ganyu casual labour, famine and HIV/AIDS in rural Malawi: causality and casualty', Journal of Modern African Studies 44, 2: 173-202.

Bryceson, D.F. \& J. Fonseca 2006. 'Risking death for survival: peasant responses to hunger and HIV/AIDS in Malawi', World Development, 8: 1654-66.

Chauveau, J-P. 2006. How does an institution evolve? Land, politics, and intergenerational relations and the institution of the tutorat among autochthons and immigrants', in R. Kuba \& C. Lentz, eds. Land Rights and the Politics of Belonging in West Africa. Leiden: Brill, 213-40.

Chimhowu, A. \& P. Woodhouse. 2006. 'Customary vs. private property rights? Dynamics and trajectories of vernacular land markets in sub-Saharan Africa', Journal of Agrarian Change 6, 3: $346-71$. 
Colin, J-P, \& M. Ayouz. 2006. 'The development of a land market? Insights from Côte d'Ivoire'. Land Economics 82, 3: 404-23.

Dorward, A. \& J. Kydd 2004. 'The Malawi 2002 food crisis: the rural development challenge', Journal of Modern African Studies 42, 3: 343-61.

Englund, H. 1999. 'The self in self interest: land, labour and temporalities in Malawi's agrarian change', Africa 69, 1: 138-59.

Ferguson, A. \& W. Mulwafu 2004. 'Irrigation reform on Malawi's Domasi and Likangala smallholder irrigation schemes: exploring land-water intersections'. Final Research Report, University of Malawi and BASIS Project, Zomba, Malawi.

Ferguson, A. \& W.O. Mulwafu, forthcoming. “"If government failed, how are we to succeed?" The importance of history and context in irrigation reform in Malawi', in B. Van Koppen, J. Butterworth \& I. Juma, eds. The Interface Between Community-Based Water Arrangements and Integrated Water Resource Management Reform in Africa. Wallingford, Oxford: CABI Publishers.

Government of Malawi (GoM). 2000. Draft National Land Policy. Version 1. Lilongwe: Ministry of Lands \& Housing.

Government of Malawi (GoM). 2002. Malawi National Land Policy. Lilongwe: Ministry of Lands \& Housing.

Griffin, K., A.Z. Rahman, \& A. Ickowitz 2002. 'Poverty and the distribution of land', Journal of Agrarian Change 1, 4: 550-74.

Harrigan, J. 1988. 'Malawi: the impact of pricing on smallholder agriculture 1971-88', Development Policy Review 6, 415-33.

Harrigan, J. 1997. 'Modeling the impact of World Bank policy-based lending: the case of Malawi's agricultural sector', Journal of Development Studies 33, 6: 848-73.

Harrigan, J. 2003. 'U-turns and full circles: two decades of agricultural reform in Malawi 19812000', World Development 31, 5: 847-63. 
Holden, S., R. Kaarhus \& R. Lunduka 2006. Land Policy Reform: the role of land markets and women's land rights in Malawi. Noragric Report No. 36. Ás: Norwegian University of Life Sciences.

Jamu, D., J. Chimphamba \& R. Brummett. 1999. 'Land use patterns in the Domasi and Likangala catchments and their effects on soil erosion, water quality, river flow rates, siltation rates on Barbus reproduction in Lake Chilwa', preliminary report, Zomba: Lake Chilwa Wetland Project.

Juul, K. \& C. Lund, eds. 2002. Negotiating Property in Africa. Portsmouth, NH: Heinemann.

Kambewa, D. 2006. 'Access and control in Lake Chilwa wetlands: an analysis of social and power relations', PhD dissertation, Bunda College of Agriculture, University of Malawi.

Kandawire, J. 1977. 'Thangata in pre-colonial and colonial systems of land tenure in southern Malawi, with special reference to Chingale', Africa 47, 2: 185-91.

Kishindo, P. 2004. 'Customary land tenure and the new land policy in Malawi', Journal of Contemporary African Studies 22, 2: 213-25.

Klopp, J.M. 2000. 'Pilfering the public: the problem of land grabbing in contemporary Kenya', Africa Today 47, 1: 7-26.

Kydd, J. \& R. Christiansen 1982. 'Structural change in Malawi since independence: consequences of a development strategy based on large-scale agriculture', World Development 10, 5: 355-75.

Lahiff, E. \& B. Cousins 2005. 'Smallholder agriculture and land reform in South Africa', IDS Bulletin 36, 2: 127-31.

Mandala, E. 1990. Work and Control in a Peasant Economy: a history of the lower Tchiri valley in Malawi, 1859-1960. Madison, WI: University of Wisconsin Press.

Mathieu, P., M. Zongo \& L. Pare. 2003. 'Monetary land transactions in western Burkina Faso: commoditisation, papers and ambiguities', in T.A. Benjaminsen \& C. Lund, eds. Securing Land Rights in Africa. London: Frank Cass, 109-28.

Mathis, S.M. 2007. 'The politics of land reform: tenure and political authority in rural KwazuluNatal', Journal of Agrarian Change 7, 1: 99-120. 
May, J., M. Carter \& V. Padayachee. 2004. 'Is poverty and inequality leading to poor growth?', South African Labour Bulletin 28, 2: 18-20.

Mbalanje, A.T.B. 1986. 'Land law and land policy in Malawi', in J.W. Arntzen, L.D. Ngcongco \& S.D. Turner, eds. Land Policy and Agriculture in Eastern and Southern Africa. Tokyo: United Nations University.

Ng'ong'ola, C. 1982. 'The design and implementation of customary land reforms in central Malawi’, Journal of African Law 26, 2: 115-32.

Ntsebeza, L. 2005. Democracy Compromised: chiefs and the politics of land in South Africa. Boston: Brill.

Nyambara, P.S. 2001. 'The closing frontier: agrarian change, immigrants and the "squatter menace" in Gokwe, 1980-1990s', Journal of Agrarian Change 1, 4: 534-49.

Peters, P.E. 1994. Dividing the Commons: Politics, Policy, and Culture in Botswana. Charlottesville and London: University Press of Virgina.

Peters, P.E. 1997. 'Against the odds: matriliny, land and gender in the Shire Highlands of Malawi', Critique of Anthropology 17, 2: 189-210.

Peters, P.E. 2002. 'Bewitching land: the role of land disputes in converting kin to strangers and in class formation in Malawi', Journal of Southern African Studies 28, 1: 155-78.

Peters, P.E. 2004. 'Inequality and social conflict over land in Africa', Journal of Agrarian Change 4, 3: 269-314.

Pike, J.G. \& G.T. Rimmington. 1965. Malawi: a geographical study. Oxford University Press.

Place, F. \& S. Otsuka. 2001. 'Population, tenure, and natural resource management: the case of customary land area in Malawi', Journal of Environmental Economics and Management 41: 1332.

Richards, P. 2005. 'To fight or to farm? Agrarian dimensions of the Mano River conflicts (Liberia and Sierra Leone)', African Affairs 104, 417: 571-90. 
Sahn, D.E., J. Arulpragasam \& L. Merid. 1990. Policy Reform and Poverty in Malawi: a survey of a decade of experience. Ithaca, NY: Cornell Food and Nutrition Policy Program Monograph 7.

Sender, J. \& D. Johnston 2004. 'Searching for a weapon of mass production in rural Africa: unconvincing arguments for land reform', Journal of Agrarian Change 4, 1\&2: 142-64.

Vail, L. 1983. 'The state and the creation of colonial Malawi's agricultural economy', in R.I. Rotberg, ed. Imperialism, Colonialism and Hunger: east and central Africa. Lexington, MA: Lexington Books, 39-88.

Walker, C. 2005. 'The limits to land reform: rethinking "the land question", Journal of Southern African Studies 31, 4: 806-24.

White, L. 1987. Magomero: portrait of an African village. Cambridge University Press. 


\section{NOTES}

${ }^{1}$. There is also a debate about the very feasibility of small-holder farming (based on reformed land tenure plus public investment) as an engine for growth and social justice, which cannot be discussed here but see the special issue of Journal of Agrarian Change 2004, volume 4, $1 \& 2$.

${ }^{2}$. The Bruce estate in what became Zomba and Chiradzulu districts was one of the last of the large estates to be broken up in the 1940s, and is the site of Peters' research villages in Zomba south.

3. 'The southern half of Nyasaland ... is an example of an area in which customary communal tenure has become immobilized at the extended family stage, despite very heavy human population densities which elsewhere might have been expected to result in a trend towards individual ownership.' Report of the Conference on African Land Tenure in East and Central Africa, Arusha, 1956, p.3 (cited in Ng'ong'ola 1982: 116).

${ }^{4}$. Personal communication, Prof Stanley Khaila (University of Malawi), Chairman of the Commission.

5. This non-capitalised term refers in general to all in the chiefly hierarchy of village heads, group village heads, and Traditional Authorities (capitalised), all of whom are called amfumu in Chichewa.

${ }^{6}$. In a paper published in 1986 , the figure given was $85 \%$ (Mbalanje 1986).

7. One is a longitudinal study of over 200 families conducted by Peters in Zomba district since 1986, here called the Zomba South Study; the other is research on small-scale irrigation under the BASIS project conducted 2001-04 in Zomba and Machinga districts by Drs Wapu Mulwafu (University of Malawi), Anne Ferguson (Michigan State University), Peters, and Dr Daimon Kambewa (then a doctoral student, University of Malawi), here called the Chilwa Study. Kambewa's sample was 240 individuals (see Kambewa 2006).

${ }^{8}$. Recent declines in prices paid for burley tobacco by the small cartel of tobacco buyers in Malawi may reduce the attraction of that crop for many smallholders.

${ }^{9}$. A child belongs to his/her mother's lineage, and the heir to a village headship or senior chiefship is through the matrilineage, usually the (classificatory) sister's son of the incumbent. 
10. This caveat is important since many documents on Malawi assert that matrilineal systems are being overtaken by patrilineal systems 'in many areas', not recognising that this is not the case everywhere (Place \& Otsuka 2001: 14). A larger issue that cannot be addressed in this paper is the prejudice against matrilinealmatrilocal systems as creating 'disincentives for long-term investment' by husbands (op.cit.). Compare the draft land policy: 'In matrilineal areas ... men are a floating population ... and most men tend not to improve land over which they have transitory tenure and no prospect of handing it on to their sons' (July 2000 draft, section 6.2.2). This blatant prejudice is without empirical evidence (the area described in this article has one of the most active and commercialised economies in the country), and echoes colonial prejudice (see the quotation from Ng'ong'ola above), as well as preconceptions of those used only to patrilineality, and to teachings by some churches and Islamic sects.

11. Local terms include mtundu (clan) and mbumba (group of sisters under the guardianship of their mother's brother).

12. A recently completed restudy of the same families (January-December 2006) will reveal whether this trend continues and how it is affected by HIV-related chronic illness and death.

13. An example of newly elaborated 'traditional' ceremonies is the engagement party (chinkhoswe) that includes elements of 'traditional' advice to the affianced couple, as well as a blatant display of new wealth through presents and literal throwing of money at the pair, activities even more marked in elite weddings.

14. This is particularly so in light of recent papers about Malawi that suggest an unreal homogeneity of 'conservative' rural inhabitants ('peasants'), mired in a socially and personally destructive and desperate 'poverty' (Bryceson 2006; Bryceson \& Fonseca 2006). Poverty there certainly is, but its dynamics are intertwined with broader socio-economic and cultural currents of wealth-making.

${ }^{15}$. In 1986/7 few rentals were recorded: one field was rented for K5 (\$1.25); 2005/6 rents for which we have most information included fields for K1200 (\$11) for 0.6ha which was being increased to K2000 (\$15) for 2006/7, K800 for 0.3ha.

16. Sales of dryland fields in 2005 to 2006 included K19,000 for a very large area (unfortunately not measured), K14000 for 0.8 ha, K6000 for 0.3 ha, K3300 for 0.06 ha (but including dimba), K3000 for 0.5 ha of bush (in the only village with uncultivated land).

${ }^{17}$. He held these fields because, unusually, he had no sisters who would have been the rightful holders of the fields. It was his mother's sisters' daughters who effected the compromise described. 


\footnotetext{
${ }^{18}$. Cf. Englund 1999: 154, who found a large increase in dimba cultivation in Dedza district.

${ }^{19}$. Paul Kishindo (Professor of Sociology, University of Malawi) finds a similar tendency in his research in Balaka (personal communication).

${ }^{20}$. Rents charged by local owners (non-chiefs who have inherited the plot) ranged from K200 to K1000 depending on size. The chiefs charged chotokhoza in bags of rice but now it seems they or some of them are charging both rent (to be paid, as for all rentals, before the season) and chotokhoza rice paid after the harvest. (According to Kishindo, this word is known as chitokhozo elsewhere in Malawi.)

${ }^{21}$. The best-known examples are the failure of the farmer credit schemes, and the massive escalation in deforestation as the forestry department and other authorities have not had the resources or the will to enforce laws on the books.

${ }^{22}$. There is a fundamental contradiction in the various policy documents between providing private titles to promote 'security' for customary land holders, and regretting the evidence on rentals and sales with 'access rights ... becoming more restrictive' (GoM 2000, para 3.9). The latter is precisely evidence of the privatisation which is a key goal of the policy!

${ }^{23}$. In theory, chiefs are separate from national government and parties but in practice, under both the Banda regime and (possibly more so) under 'multi-party' politics, they have become politicised and manipulated. There is also a move among the most prominent chiefs (eg. the Chewa and Ngoni 'paramounts') to call for a House of Chiefs in the name of 'tradition'. The debate about the role of chiefs and chiefship is (re)engaging many in other countries of Southern Africa (for example, Beall et al. 2005, Mathis 2007, Ntsebeza 2005).

${ }^{24}$. During the most recent distribution of subsidised fertiliser (September-October 2006), several of the new villages found themselves without the expected numbers of coupons, and some of the higher level chiefs were scrambling to take from one to give to another.

25. The literature is huge, but see Amanor 2001, Bassett \& Crummey 1993, Berry 2002, Chimhowu \& Woodhouse 2006, Juul \& Lund 2002, Peters 2004.
} 